\title{
ЕТИКА І ДЕОНТОЛОГІЯ В НАВЧАЛЬНОМУ ПРОЦЕСІ СТУДЕНТА-МЕДИКА
}

\author{
С. І. Корнага, О. В. Денефіль, 3. П. Мандзій \\ ДВНЗ “Тернопільський державний медичний університет імені І. Я. Горбачевського МОЗ Украйни”
}

\section{ETHICS AND DEONTOLOGY IN EDUCATIONAL PROCESS OF A MEDICAL STUDENT}

\author{
S. I. Kornaha, O. V. Denefil, Z. P. Mandziy \\ SHEI "Ternopil State Medical University by I. Ya. Horbachevsky of MPH of Ukraine"
}

\begin{abstract}
Стаття присвячена питанням етики та деонтології в процесі навчання в медичному вузі. Особлива увага звертається на питання спілкування пацієнта і майбутнього лікаря, удосконалення його професійної майстерності, оскільки в руки медиків віддається найдорожче - життя і здоров'я людини.
\end{abstract}

This article is devoted to ethics and deontology during training in the medical university. Particular attention is paid to patient communication and future doctor, improvement of his professional skills as well as in the hands of physicians is given the most precious - life and health.

Вступ. Медичні працівники зобов' язані знати і постійно дотримуватися правових і моральних норм, що забезпечують професійну бездоганність у роботі, іï етико-деонтологічну спрямованість.

Хороший медик-це не тільки людина, яка отримала грунтовну спеціальну підготовку, але й вміє застосовувати свої знання в інтересах хворого, тобто дотримується норми медичної деонтології. Мова йде не просто про належну поведінку медичного персоналу, а про виключення шкідливих наслідків неповноцінної діяльності медичного працівника.

Перед лікарем будь-якої спеціальності при першому знайомстві з хворим стоїть завдання заспокоїти його, зняти емоційне напруження, налаштувати на успіх лікування, вселити надію на одужання. Щоб вирішити це нелегке завдання, необхідний повний контакт і взаєморозуміння, терпіння, вміння слухати хворого, співпереживати стражданням хворої людини.

Етика і деонтологія - це єдині поняття. Вони визначають роль етичних і моральних норм в житті і діяльності людини.

Основна частина. Формування етико-деонтологічних принципів і світогляду майбутнього лікаря й основ його професійних знань, по суті, починається ще з моменту вступу в медичний вуз. Випускними ж іспитами лише формально завершується академічний етап першочергового накопичення і систематизації знань і починається безперервний, протягом

( С. І. Корнага, О. В. Денефіль, 3. П. Мандзій усього життя, етап вдосконалення і спеціалізації професійної майстерності.

На практичних і семінарських заняттях, особливо на першому курсі, втілення в навчальний процес принципів медичної етики і деонтології мають деякі труднощі. Проте вони є цілком переборними, якщо зовнішнє оформлення навчальних кімнат, наочні засоби сприяють формуванню поняття про місце лікаря в суспільстві, про його професійний обов' язок і поєднуються з вимогою постійного дотримання високих принципів етики взаємовідносин викладача і студентів, відношень студентів між собою.

Гарне зовнішнє оформлення вузу, навчальних кімнат, змістовні лекції та практичні заняття відіграють особливо важливу виховну роль. Студенти повинні постійно відчувати атмосферу високої медичної культури. В таких випадках говорять, що “і стіни навчають". Викладачі повинні слідкувати за тим, щоб в лікарняних і поліклінічних умовах студенти чітко дотримувалися встановлених норм медичної етики та деонтології.

У процесі навчання майбутній лікар, крім медикобіологічної та загальної підготовки, повинен засвоїти основи багатьох медичних дисциплін, навчитися правильно на високому професійному рівні обстежувати і лікувати хвору людину. Пацієнти, крім знань, вимагають до себе уваги, чуйності і здатності зрозуміти їх переживання. Навчити студентів за такий нетривалий термін перебування у вузі цьому мистецтву дуже важке завдання. Професійна підготовка меди- 
ка не вкладається у встановлений регламент навчального часу, вона вимагає від людини, яка присвятила себе медицині, самовідданості та самовдосконалення, максимальної віддачі духовних та фізичних сил і відданості справи, оскільки в руки медиків віддається найдорожче - життя і здоров'я людини. В цьому плані необхідно проводити виховну роботу зі студентами як під час навчання, так і в позаурочний час протягом всього навчання у медичному вузі.

Зустріч студентів $з$ пацієнтами - завжди хвилююча подія в їхньому житті. Майже усі хворі для студентів молодших курсів медичного вузу є людьми похилого віку, нерідко старшими за їхніх батьків. Тому цілком зрозуміла боязкість студентів при спілкуванні 3 пацієнтами. Як підійти? 3 чого розпочати розмову? Студент намагається в усьому копіювати викладача: в манері розмови, оформленні медичної документації, виконанні різних маніпуляцій тощо. Це інколи виглядає комічно і бентежить студента. Встановлення контакту з хворим - це, до певної міри, мистецтво, яке пов'язане не лише з бажанням, але вимагає певного психологічного настрою і виробляється в процесі практики [1]. Кожен студент повинен про це знати i, готуючись до зустрічі з хворим, постійно слідкувати за своїми манерами, мовою, зовнішнім виглядом.

Зовнішній вигляд студента повинен відповідати пропонованим вимогам і не викликати негативної реакції з боку хворого. Для медика дуже важливо, щоб його зовнішній вигляд завжди був охайним. Студенти повинні чітко усвідомити, що охайний вигляд, чистий $і$ випрасуваний медичний халат і шапочка самі по собі мають сприятливий психотерапевтичний вплив на хворого. Ці зовнішні атрибути ніби підкреслюють високу гуманність, чистоту думок і благородство професії лікаря. Викладачі зобов'язані протягом усіх років навчання стверджувати у свідомості студентів цю думку.

При зустрічі з хворим студент повинен дотримуватися обов' язкових елементів комунікативних навичок, тобто приязна усмішка при першій зустрічі та під час спілкування, привітання, представлення, встановлення довірчих взаємовідносин, збір анамнезу, обгрунтування доцільності проведення відповідних фізикальних методів обстеження, пояснення результатів обстеження та планування наступних дій, завершення розмови. Якщо виникає необхідність обстеження, то не рекомендується сідати на ліжко хворого, а потрібно користуватися стільцем. При розмові студент повинен дивитися в очі пацієнта і спостерігати за його мімікою. Це сприяє відвертій розмові, а спостереження дає можливість передбачати, в якому аспекті більш доцільно вести бесіду [2]. В розмові $з$ пацієнтом недоцільна фамільярність, необхідно вибирати вирази і задавати лише ті запитання, які відносяться до суті справи.

Майбутній лікар повинен опанувати мистецтвом вислуховувати хворого. Необхідні певний такт і витримка, щоб, не перебиваючи пацієнта, вислухати його. Уважне вислуховування дозволяє зрозуміти внутрішній світ хворого зі всіма його хвилюваннями і тривогами та сприяє встановленню хорошого контакту і взаєморозуміння [2]. В багатьох випадках воно приносить хворому не менше полегшення, ніж призначення седативних лікарських середників.

Значна увага в процесі навчання повинна бути присвячена оформленню медичної документації. Студенти з перших кроків своєї роботи повинні навчитися правильно і чітко заповнювати медичну документацію, починаючи від найпростішої і до найскладнішої. Недбале оформлення направлення на аналізи, рецептурних бланків тощо - ознака халатності і безкультур'я.

У студентів необхідно виховувати почуття колективізму і високі принципи етичних відносин між медичними працівниками. Грубість, нетактовність, недружелюбність між медиками недопустимі в межах медичного закладу, де завжди повинен панувати дух товариськості, доброти, співчуття, участі та взаємної підтримки. Без цього неможливо досягти ефективного психотерапевтичного впливу середовищем на психіку хворих. На практичних заняттях і на лекціях необхідно постійно утверджувати ці принципи [3].

Медицина - одна з найдавніших галузей суспільної практики-пройшла довгий і важкий шлях. В процесі iii становлення як наукової дисципліни значний вплив мали рівень соціально-економічного та культурного розвитку, які панували в суспільстві. Кожний етап історії знаменувався для медицини новими надбаннями як у сфері теоретичних уявлень, так і в практичній діяльності, лікуванні і профілактиці захворювань. В ділянці нагромадження знань значну роль завжди відігравала наступність знань - спочатку від батька до сина або у вузькому колі сімейно-родинних традицій, потім в межах медичних шкіл і пізніше медичних факультетів університетів.

Поступово медицина стала являти собою систему наукових знань про здоров'я і хвороби людини одну із найгуманніших сфер суспільної практики. Тисячоліттями вироблялися гуманістичні принципи медицини, згідно $з$ якими медики не мають права заподіяти шкоду здоров'ю людини, прирікати людину на загибель, використовувати ії тяжке становище 
3 метою збагачення. При спілкуванні з пацієнтами та їх родичами лікар повинен постійно пам'ятати про принципи психотерапії і вміти користуватися психотерапевтичними методами у своїй повсякденній роботі.

На сьогодні найновіші досягнення медичної науки і техніки змушують дещо по-іншому розглядати традиційні норми медичної деонтології. Старий ланцюжок "лікар-пацієнт" замінюється новим "лікар-прилад-пацієнт”, а потреба самого пацієнта у чуйному та уважному ставленні лікаря, у його доброму слові, що вселяє надію, не зменшилась, - про це лікар повинен завжди пам'ятати. Технологічний прогрес у медицині не повинен відсувати на задній план особистість пацієнта. Медицина була і завжди буде медициною особистості, медициною для людини з їі складним світоглядом [4].

Довіра-один із наріжних каменів медицини. Хворий буде лікуватися лише у того спеціаліста, якому довіряє. Контакт лікаря з хворим - це вже лікувальний процес. В. М. Бехтерев наголошував: “Якщо хворому після розмови з лікарем не стає легше - це не лікар". Медик, який не має довіри хворого, не прагне до полегшення його моральних страждань, лікувати

\section{Література}

1. Харди И. Врач, сестра, больной. Психология работы с больными / И. Харди. - Budapest :Akademiai Kiado, 1974.$286 \mathrm{c}$.

2. Ковальчук Л. Я. Алгоритм спілкування студентів (лікарів) з пацієнтами (методичні рекомендації) / Л. Я. Ковальчук та ін. - Тернопіль : ТДМУ, 2009. -40 с. не може. Щоб завоювати довіру хворих, мати в нього авторитет, треба стати добрим лікарем, а щоб стати ним, треба прагнути не лише до збільшення професійних знань, а й до самовдосконалення душевних якостей (постійної відкритої доброти, любові до людей). Це повинно стати звичкою, другою натурою [4].

Професія лікаря - одна з найважчих професій, що іноді вимагає відмови від цілої низки життєвих благ. Здоров'я - перша і найнеобхідніша умова благополуччя і всієї нашої діяльності. Чи потрібен який-небудь інший стимул, окрім розуміння, що ти повернув людині життя? Це розуміння зводить нанівець іноді несправедливе судження про лікаря, його безсонні ночі і хвилювання. Хай там що, але лікар отримує радість від повернутого людям здоров'я та життя.

Висновок. Високі принципи моралі лікаря, постійна готовність прийти на допомогу хворому, діяльне милосерддя та доброта, високий професіоналізм та відповідальність за свою роботу, безкорисливість, прагнення постійно удосконалювати свій професійний i загальнокультурний рівень, відрізняють переконаного та справжнього лікаря, майстра своєї справи від ремісника, який випадково став лікарем.

3. Острополец С. С. Современные аспекты медицинской этики и деонтологии / С. С. Острополец // Новости медицины и фармации. - 2009. - № 15. - С. 23-24.

4. Процюк Р. Г. Морально-етичні аспекти у фтізіатрії / Р. Г. Процюк // Здоров’я України. - 2007. - № 7. - С. 40, 45. 